\section{Loyalitas Kreativitas \\ Aldi Masyarakat Kreatif}

P-ISSN 2722-2101, E-ISSN 2722-4201

Program Studi Ekonomi Manajemen Universitas Pamulang

Jurnal LOKABMAS Kreatif Vol.02,No.03.Nov 2021 Hal.65-73

Email:jurnalkreatif.manajemen@gmail.com

\title{
PENGARUH TEKNOLOGI DALAM DUNIA PENDIDIKAN UNTUK GURU DAN PARA SISWA SMPN 13 DI TANGERANG SELATAN
}

\author{
R. Chepi Safei Jumhana, Achmad Sumali, Syarifah Ida Farida, \\ Dira Karlina, Surasni \\ Dosen Fakultas Ekonomi dan Pendidikan Ekonomi Universitas Pamulang \\ Email : \\ dosen00570@unpam.ac.id, dosen01562@unpam.ac.id, dosen01477@unpam.ac.id, \\ dosen01553@unpam.ac.id, dosen01520@unpam.ac.id
}

\begin{abstract}
ABSTRAK
Kegiatan Pengabdian Kepada Masyarakat ini bertujuan untuk memberikan Pelatihan kepada Para Peserta Didik atau Siswa SMPN 13 Tangerang Selatan dalam memberi Pengetahuan tentang Perkembangan Teknologi Dalam Dunia Pendidikan meliputi Sejarah Perkembangan Teknologi, dan Dampak Dari PerkembanganTeknologi. Adapun metode yang dilakukan dengan penyampaian materi dan SimulasiAplikasi-aplikasi pembelajaran.

Adapun hasil kegiatan pengabdian masyarakat memberikan pengetahuan tentang sejarah perkembangan teknologi, pengaruh yang diberikan dalam dunia Pendidikan serta dampak negative dari perkembangan teknologi, sehingga peserta didik khususnya Siswa SMPN 13 Tangerang Selatan langsung dapat merasakan dari pelatihan ini.

Metode yang dilakukan dalam pengabdian Masyarakat yang dilaksanakandengan SMPN 13 Tangeran Selatan, didahului dengan tatap muka dengan Kepala Sekolah SMPN13 Tangerang Selatan untuk membicarakan permasalahan yang dihadapi dalam pelaksanaan pembelajaran jarak jauh di masa pandemi ini, agar pembelajaran tetap optimal walau dilaksanakan tanpa tatap muka, dengan memberikan materi pembelajaran dengan mensimulasikan aplikasi-aplikasi dan memanfaatkan media sosial agar pembelajaran menjadi menarik serta menumbuhkan kreatifitas Peserta Didik khususnya Siswa SMPN 13 Tangerang Selatan
\end{abstract}

\section{Kata Kunci : PKM, Pengetahuan, Perkembangan Teknologi}

\begin{abstract}
ABSTRAC
This Community Service Activity aims to provide training to students or students of SMPN 13 South Tangerang in providing knowledge about technological developments in the world of education including the history of technological development, and the impact of technological developments. The method used is the delivery of material and simulation of learning applications.

The results of community service activities provide knowledge about the history of technological development, the influence it has in the world of education and the negative impact of technological developments, so that students, especially students of SMPN 13 South Tangerang, can immediately feel from this training.

The method used in community service carried out with SMPN 13 South Tangerang, was preceded by face-to-face with the Principal of SMPN13 South Tangerang to discuss the problems faced in the implementation of distance learning during this pandemic, so that learning remains optimal even
\end{abstract}




\section{Loyalitas Kreativitas \\ Aldi Masyarakat Kreatif}

P-ISSN 2722-2101, E-ISSN 2722-4201

Program Studi Ekonomi Manajemen Universitas Pamulang

Jurnal LOKABMAS Kreatif Vol.02,No.03.Nov 2021 Hal.65-73

Email:jurnalkreatif.manajemen@gmail.com

though it is carried out without face to face, with provide learning materials by simulating applications and utilizing social media so that learning becomes interesting and fosters the creativity of students, especially students of SMPN 13 South Tangerang

\section{Keywords: PKM, Knowledge, Technological Development}

\section{PENDAHULUAN}

\section{Analisis Situasi Permasalahan}

Di era globalisasi kemajuan teknologi yang mengglobal telah terpengaruh dalam segala aspek kehidupan baik di bidang ekonomi, politik, kebudayaan, seni dan bahkan di dunia pendidikan. Kemajuan teknologi adalah sesuatu yang tidak bisa kita hindari dalam kehidupan ini, karena kemajuan teknologi akan berjalan sesuai dengan kemajuan ilmu pengetahuan. Setiap inovasi diciptakan untuk memberikan manfaat positif bagi kehidupan manusia. Memberikan banyak kemudahan, serta sebagai cara baru dalam melakukan aktifitas manusia. Khusus dalam bidang teknologi informasi sudah menikmati banyak manfaat yang dibawa oleh inovasi-inovasi yang telah dihasilkan dalam dekade terakhir ini. Namun demikian, walaupun pada awalnyadiciptakan untuk menghasilkan manfaat positif, di sisi lain juga memungkinkan digunakan untuk hal negatif.

Munculnya penyakit pneumonia yang tidak seperti biasanya, awal munculnya di kota Wuhan, provinsi Hubei negara China. Penyebarannya sangat cepat, awal tahun 2020 penyakit ini telah menyebar di berbagai provinsi lain di China, menyebar juga ke negara Thailand, Jepang, dan Korea Selatan, dan hampir 190 negara terserangpenyakit ini, sehingga menjadi pandemi. WHO mengumumkan nama penyakit ini yaitu Coronavirus Disease (Covid-19) yang disebabkan oleh virus Severe Acute Respiratory Syndrome Coronavirus-2 (SARS-CoV-2). Penyakit ini dilaporkan masuk ke Indonesia awal Maret 2020, sejumlah kasus di kota Bogor, kemudian dengan cepatnya menyebar ke wilayah lain seperti Jakarta, Bandung,dan wilayah lain di pulau Jawa dan luar Jawa. Pada 16 Maret 2020, pemerintah mengumumkan agar masyarakat stay at home, work from home sebagai upaya mencegah penyebaran penyakit ini, seperti menghindari interaksi langsung, kerumunan, jaga jarak dan menjaga imun tubuh agar tetap meningkat.

\section{Rumusan Masalah}

Dari kondisi diatas, maka dirumuskan masalah sebagai berikut :
1. Bagaimana Proses perkembangan Teknologi pada Dunia Pendidikan?

2. Bagaimana Teknologi memberikan manfaat bagi Pendidikan/pembelajaran?
3. Apa sajakah pengaruh negatif Teknologi informasi bagi kegiatan Pendidikan?

\section{Tujuan Pengabdian Kepada Masyarakat}

Dalam Tri Darma Perguruan Tinggi ada tiga kewajiban yang harus dijalankan oleh Perguruan Tinggi dalam mengelolah seluruh komponen yang ada didalamnya (civitas akademika).

\section{Dharma Pendidikan Pengajaran}

Dharma pendidikan pengajaran adalah kegaitan yang berorientasi pada transfer ilmu pengetahuan baik bersifat teori maupun praktek di dalam lingkungan perguruan tinggi. Yang melibatkan kurikulum, sarana prasarana pendidikan dan pengajaran.

tenaga pengajar (dosen), peserta didik (mahasiswa), tenaga non edukadi (pgawai administrasi) dan lainnya sebagainya.

\section{Dharma Penelitian}

Dharma penelitian merupakan kegiatan dalam upaya menghasilkan pengetahuan empiric, teori, konsep, metodologi, model , 


\section{Loyalitas Kreativitas \\ Aldi Masyarakat Kreatif}

P-ISSN 2722-2101, E-ISSN 2722-4201

Program Studi Ekonomi Manajemen Universitas Pamulang

Jurnal LOKABMAS Kreatif Vol.02,No.03.Nov 2021 Hal.65-73

Email:jurnalkreatif.manajemen@gmail.com atau informasi baru yang memperkaya ilmu pengetahuan, teknologi dan atau kesenian

\section{Dharma Pengabdian Masyarakat}

Pengabdian kepada masyarakat pada hakikatnya membantu masyarakat agar masyarakat mau dan mampu memenuhi kebutuhannya sendiri. Dengan demikian azas pengabdian kepada masyarakat sesuai dengan azas kemanusia yang menenkankan pada usaha pengembangan masyarakat sebagai subyek pembangunan. Kemudian pengabdian kepada masyarakat harus dilandasi pada kepercayaan dan kemampuan serta kekuatan masyarakat itu sendiri.

Pengabdian kepada masyarakat yang dilakukan oleh dosen sebagai salah satu dharma atau tugas pokok perguruan tinggi. Dengan dilaksanakannya Tri Dharma Perguruan Tinggi kepada masyarakat dalam bentuk pelatihan, dll diharapkan ada keterkaitan bahkan kebersamaan antara perguruan tinggi dan masyarakat. Hal ini dapat diartikan sebagai: pengamalan IPTEK melalui metode ilmiah langsung kepada masyarakat yang membutuhkan, dalam upaya mensukseskan pembangunan, mengembangkan manusi ke dalam sektor pembangunan dan meningkatkan taraf kehidupan masyarakat.

\section{TINJAUAN PUSTAKA}

\section{Sejarah Perkembangan Teknologi}

Di masa pandemi Covid 19 yang sedang mewabah di banyak negara termasuk Indonesia menuntut semua kegiatan dilakukan di rumah, bekerja dari rumah, belajar dari rumah sehingga segala aktifitas manusia membutuhkan Teknologi.

Penggunaan Teknologi dalam Pembelajaran menjadi solusi mengatasi belajar dari rumah, Menurut Kamus Besar Bahasa Indonesia (KBBI), kata teknologi mengandung arti metode ilmiah untuk mencapai tujuan praktis, ilmu pengetahuan terapan atau keseluruhan sarana untuk menyediakan barang- barang yang diperlukan bagi kelangsungan dan kenyamanan hidup manusia. Saat ini teknologi telah menyentuh hampir semua bidang kehidupan manusia.

Teknologi Informasi (TI) adalah suatu teknologi yang dapat membantu manusia dalam menyampaikan informasi kepada orang lain dalam waktu yang cepat dan tepat. Teknologi ini terdiri dari seperangkat perangkat lunak dan perangkat keras yang digunakan untuk memproses, mentransfer, dan menyimpaninformasi. Alat-alat teknologi informasi ini memberikan informasi secara akurat dan terkini kepada individu yang tepat pada waktu yang tepat. Dalam perkembanganya Teknologi mengalami perubahan dan berkembang secara bertahap dari masa ke masa, secara singkat dapat dijelaskan sebagai berikut

\section{Masa Pra Sejarah}

Manusia pada zaman pra sejarah menggunakan peralatan yang dibuat dari berbagai benda di sekitarnya, seperti; batu, besi, dan perunggu. Pada masa pra sejarah, teknologi yang digunakan manusia pun mengalami perkembangan dari waktu ke waktu. Beberapa contoh peralatan tersebut di antaranya; kapak genggam, pisau, pedang, bejana, tembikar, dan lain sebagainya.

\section{Masa Sejarah}

Pada zaman sejarah, manusia telah mengenal tulisan dan berbagai teknologi yang sudah berkembang, seperti; konstruksi, maritim, pertanian, dan peralatan menulis. Beberapa contoh hasil teknologi yang diciptakan manusia pada masa inidi antaranya; kapal laut, Piramid, jam matahari, mercusuar, dan lain sebagainya. 


\section{Loyalitas Kreativitas \\ Aldi Masyarakat Kreatif}

P-ISSN 2722-2101, E-ISSN 2722-4201

Program Studi Ekonomi Manajemen Universitas Pamulang

Jurnal LOKABMAS Kreatif Vol.02,No.03.Nov 2021 Hal.65-73

Email:jurnalkreatif.manajemen@gmail.com

\section{Masa Abad Pertengahan}

Teknologi pada masa abad pertengahan hingga era modern telah mengalami perkembangan yang cukup maju. Pada era ini, manusia telah berhasilmelakukan berbagai penemuan di bidang medis, matematika, astronomi, kartograf, militer, dan lainnya. Beberapa contoh hasil teknologi di masa abad pertengahan hingga era modern, di antaranya; sistem navigasi kapal, aljabar, mesin cetak, dan lain sebagainya.

\section{Masa Era Revolusi Industri}

Ini merupakan era di mana manusia telah berhasil menemukan berbagai jenis mesin untuk melakukan pekerjaan manusia. Era revolusi industri disebutsebut sebagai cikal bakal perkembangan teknologi saat ini. Beberapa contoh hasil teknologi di era revolusi industri, di antaranya; telepon, telegram, telegraph, mobil generasi awal, sepeda, mesin tenun, mesin uap, dan lain sebagainya.

\section{Abad 20 \\ Perkembangan teknologi mengalami kemajuan yang sangat cepat pada abad. Di masa inilah pertamakali manusia berhasil menciptakan alat transportasi keluar angkasa dan mendarat di bulan (Neil Armstrong). Pada abad 20, manusia berhasil menciptakan berbagai objek baru, seperti; transistor (cikal bakal komputer kecil), internet, bom atom, televisi, kulkas, microwave, vaksin, dan lain sebagainya.}

\section{Abad 21}

Di abad 21, teknologi semakin mempengaruhi berbagai kehidupan manusia di berbagai bidang. Mulai dari pekerjaanpekerjaan berat, pendidikan, kehidupan sosial, hingga kegiatan rumah tangga, semuanya telah tersentuh oleh teknologi

Beberapa contoh yang termasuk dalam teknologi informasi diantaranya
Televisi,Radio, Media online (website, blog, portal).

\author{
Jenis - Jenis Teknologi \\ Beberapa Jenis Teknologi dapat \\ disampaikan diantaranya sebagai berikut :
}

\section{Teknologi Komunikasi}

Teknologi komunikasi merupakan suatu teknologi yang dapat membantu manusia dalam berkomunikasi satu sama lain dan saling mengirimkan informasi dengan menggunakan suatu perangkat khusus. Teknologi komunikasi salah satu teknologi yang paling umum dan banyak digunakan dalam kehidupan kita sehari- hari. Kemajuan teknologi telah meningkatkan cara menyampaikan informasi dari satu tempat ke tempat lain dengan lebih nyaman, cepat, dan dengan akurasi yang tinggi. Adapun contoh dari dalam teknologi komunikasi diantaranya Smartphone, Email, Mesin fax, Aplikasi chatting.

\section{Teknologi Transportasi}

Teknologi transportasi merupakan suatu teknologi yang membantu manusia untuk berpindah tempat (transportasi) dari suatu lokasi ke lokasi lainnya dalam waktu yang cepat, berapa contoh yang termasuk dalam teknologi transportasi diantaranya : Kereta listrik, Mobil listrik, Pesawat, Kapal laut, Rekayasa jalan raya.

\section{Teknologi Pendidikan}

Teknologi pendidikan adalah teknologi yang berhubungan dengan dunia pendidikan dimana kegiatannya memanfaatkan alat bantu tertentu. Teknologi pendidikan bertujuan untuk meningkatkan kinerja siswa dengan mengelola dan membangun sumber daya dan proses teknologi yang berbeda di kelas atau lingkungan belajar apa pun, berikut beberapa contoh yang termasuk teknologi Pendidikan diantaranya :

1. Metode pengajaran terbaru 


\section{Loyalitas Kreativitas Aldi Masyarakat Kreatif}

P-ISSN 2722-2101, E-ISSN 2722-4201

Program Studi Ekonomi Manajemen Universitas Pamulang

Jurnal LOKABMAS Kreatif Vol.02,No.03.Nov 2021 Hal.65-73

Email:jurnalkreatif.manajemen@gmail.com

\section{Pembelajaran secara online}

3. Peralatan laboratorium sekolah

4. Lab computer

\section{Perkembangan Teknologi (internet) dalam dunia pendidikan.}

Menghadapi abad ke-21, UNESCO melalui "The International Commission on Education for the Twenty First Century" merekomendasikan Pendidikan yang berkelanjutan (seumur hidup) yang dilaksanakan berdasarkan empat pilar proses pembelajaran, yaitu : Learning to know (belajar untuk menguasai pengetahuan), learning to do (belajar untuk mengetahui keterampilan), learning to be (belajar untuk mengembangkan diri), dan Learningto live together (belajar untuk hidup bermasyarakat), untuk dapat mewujudkan empat pilar pendidikan di era globalisasi informasi sekarang ini, para guru sebagai agen pembelajaran perlu menguasai dan menerapkan Teknologi Informasi dan Komunikasi dalam pembelajaran.

Menurut Rosenberg ( 2001 ), dengan berkembangnya penggunaan TIK ada beberapa pergeseran dalam proses pembelajaran yaitu:

a. Dari ruang kelas ke dimana dan kapan saja,

b. Dari kertas ke "on line" atau saluran, c. Dari fasilitas fisik ke fasilitas jaringan kerja

Komunikasi sebagai media pendidikan dilakukan dengan menggunakan mediaRobin Paul Ajjelo juga mngemukakan secara ilustratif bahwa di masa-masa mendatang isi tas anak sekolah bukan lagi buku-buku dan alat tulis seperti sekarang ini, akan tetapi berupa:

Komputer notebook dengan akses internet tanpa kabel, yang bermuatan materi-materi belajar yang berupa bahan bacaan, materi untuk dilihat atau di dengar, dan dilengkapi dengan kamera digital serta perekam suara.

Jam tangan yang dilengkapi dengan data pribadi, uang elektronik, kodesecurity untuk masuk rumah, kalkulatordan sebagainya.

Videophone bentuk saku dengan perangkat lunak, akses internet, permainan,musik, dan TV.Alat-alat musik.Alat-alat olahraga. Bingkisan untuk makan siang.

Sedangkan untuk media sosial dapat berkontribusi dalam pembelajaran jarak jauh dengan menggunakan daring, seperti media Washapt, Zoom Meet, Google Meet dan lainnya.

Hal itu menunjukkan bahwa gejala kelengkapan anak sekolah dimasa itu nanti berupa perlengkapan yang bernuansa Internet sebagai alat bantu belajar,

Sebagai sebuah proses, teknologi pendidikan bersifat abstrak. Dalam hal ini teknologi pendidikan bisa dipahami sebagai sesuatu proses yang kompleks, dan terpadu yang melibatkan orang, prosedur, ide, peralatan, dan organisasi untuk menganalisis masalah, mencari jalan untuk mengatasi permasalahan, melaksanakan, menilai dan mengelola pemecahan masalah tersebut yang mencakup semua aspek belajar manusia (AECT, 1977), Sejalan dengan hal tersebut, maka lahirnya TeknologiPendidikan yang mencuat saat ini, meliputi pemerataan kesempatan memperoleh pendidikan, peningkatan mutu/kualitas, relevansi, dan efisiensi pendidikan. Permasalahan serius yang masih dirasakan oleh pendidikan mulai dari pendidikan dasar hingga pendidikan tinggi adalah masalah Kualitas tertentu saja, ini dapat dipecahkan melalui pendekatan 


\section{Loyalitas Kreativitas \\ Aldi Masyarakat Kreatif}

P-ISSN 2722-2101, E-ISSN 2722-4201

Program Studi Ekonomi Manajemen Universitas Pamulang

Jurnal LOKABMAS Kreatif Vol.02,No.03.Nov 2021 Hal.65-73

Email:jurnalkreatif.manajemen@gmail.com
Teknologi Pendidikan.

media komunikasi seperti telepon, komputer, internet, e-mail, dan media sosial lainnya seperti Washapt, Zoom . Interaksi antar guru dan siswa tidak hanya dilakukan melalui hubungan tatap muka dan juga dilakukan dengan menggunakan media-media.

tersebut. Guru dapat memberikan layanan tanpa harus berhadapan langsung dengan siswa. Demikian pula siswa dapat memperoleh informasi dalam lingkup yang luas dari berbagai sumber media cyber space atau ruang maya dengan menggunakan komputer atau internet.

Hal yang paling mutakhir adalah berkembangnya apa yang disebut "cyber teaching" atau pengajaran Maya, yaitu proses pembelajaran yang dilakukan dengan menggunakan internet. Istilah lain yang makin populer saat ini ialah e-learning yaitu satu model pembelajaran dengan menggunakan media Teknologi Komunikasi dan Informasi khususnya Internet. Menurut Rosenberg (2001), e-learning merupakan satupenggunaan Tekonologi Internet dalam penyampaian pembelajaran dalam jangkauan luas yang berlandaskan tiga kriteria, yaitu:

\section{a. E-learning merupakan jaringan dengan kemampuan untuk memperbaharui,menyimpan, mendistribusi dan membagi materi ajar atau Informasi, \\ b. Pengiriman sampai kepengguna terakhir melalui komputer dengan menggunakan teknologi Internet yang standar, \\ c. Memfokuskan pada pandangan yang paling luas tentang pembelajaran di balik paradigma pembelajaran tradisional.}

Sejalan dengan perkembangan Teknologi Informasi dan Komunikasi itu sendiri pengertian e-learning menjadi lebih luas yaitu pembelajaran yang pelaksanaannya didukung oleh jasa teknologi seperti telepon, audio, videotape, transmisi satellite atau komputer.

Teknologi pembelajaran terus mengalami perkembangan seiring dengan perkembangan zaman. Dalam pelaksanaan pembelajaran sehari-hari kita sering jumpai adanya pemfaatan dari perkembangan Teknologi dalam dunia pendidikan, seperti yang sering dilakukanoleh guru atau dosen yaitu mengkombinasikan alat teknologi dalam peroses pembelajaran. Internet merupakan salah satu alat komunikasi yang murah dimana memungkinkan terjadinya interaksi antara dua orang atau lebih. Kemampuan dan karakteristik internet memungkinkan terjadinya proses belajar mengajar jarak jauh (E-learning) dan media social lainnya menjadi lebih efektif dan efisien sehingga dapatdiperoleh hasil yang maksimal.

\section{Dampak Negatif Perkembangan Teknologi dalam Dunia Pendidikan}

Dalam kehidupan sehari-hari, Teknologi itu tidak hanya mendatangkan dampak positif, melainkan juga akan dapat mendatangkan dampak negatif, inilah yang harus tetap kita waspadai. Mengingat saat sekarang ini sering kita jumpai dimana-mana banyak para pelajar dan mahasiswa yang sering menggunakan fasilitas Teknologi tidak sesuai dengan yang diharapkan, sehingga hal ini dapat mendatangkan dampak yang negatif.

\section{Situs-Situs yang tidak Mendidik}

Terdapatnya berbagai macam situs-situs yang tidak mendidik, dan membuat pengguna menjadi rusak atau terpengaruh akal pikirannya, seperti situs porno, perjudian dan lain sebagainya.

\section{Pengguna menjadi malas}

Membuat penggunanya menjadi malas dalam satu sisi yang lain, akibat kecanggihan teknologi ini, sehingga membuat pengguna malas dalam aktifitas membantu orangtua.

\section{Tindak kriminal}

Tindak seperti Cybercrime yang dimana kejahatan ini dilakukan seseorang 


\section{Loyalitas Kreativitas Aldi Masyarakat Kreatif}

P-ISSN 2722-2101, E-ISSN 2722-4201

Program Studi Ekonomi Manajemen Universitas Pamulang

Jurnal LOKABMAS Kreatif Vol.02,No.03.Nov 2021 Hal.65-73

Email:jurnalkreatif.manajemen@gmail.com dengan perantara teknologi internet ini, sehingga Mencetak generasi yang berpengetahuan tetapi mempunyai moral yang rendah.

\section{Munculnya media massa}

Munculnya media massa, khususnya media elektronik sebagai sumber ilmu dan pusat pengetahuan yang disalah gunakan oleh pelajar

\section{Metode Kegiatan PKM}

1.

1. Penyuluhan, penyampaian materi Perkembangan Teknologi, meliputi Sejarah Perkembangan Teknologi dan manfaat dan dampak dari perkembangan Teknologi Slide Power Point (PPT)

2. Simulasi dalam Penggunaan berbagai Metode Pembelajaran sehingga pembelajaran menjadi menarik, dan menumbuhkan kreatifitas dan inovasi.

\section{Hasil PKM}

Pelaksanaan Pengabdian kepada masyarakat dengan metode penyuluhan melalui media on line dengan aplikasi zoom meeting melakukan penyampaian materi kepada Siswa SMPN 13 Tangerang Selatan oleh Dosen Universitas Pamulang, dengan melibatkan Kepala Sekolah SMPN 13 Tangerang Selatan, sebagai Penanggung Jawab Kegiatan Sekolah.

Ibu Ratna selaku Kepala Sekolah sangat mendukung Pelaksanaan kegiatan Pengabdian Kepada Masyarakat dengan target luaran yang dihasilkan dari kegiatan ini adalah Siswa mengetahui pengetahuan tentang Pengaruh Perkembangan Teknologi dalam Dunia Pendidikan sehingga menjadi solusi dalam pembelajaran jarak jauh karena harus belajar dari rumah dikarenakan kondisi wabah Covid 19.

Adapun materi yang disampaikan meliputi Materi Sejarah Perkembangan
Teknologi, Materi Pengaruh Perkembangan Teknologi Dalam Dunia Pendidikan, yang membuat pembelajaran menjadi menarik dengan penggunaan aplikasi-aplikasi pembelajaran yang inovatif dan kreatifitas yang tinggi, dan metode dan berbagai dampak pengembangannya.

Kegiatan pengabdian kepada masayarakat ini menggabungkan bagaimana Metode Pembelajaran dengan menggunakan aplikasi yang menarik, antusias serta mempermudah Siswa menerima pengatahuan yang disampaikan.

Kegiatan ini juga menumbuhkan motivasi belajar Siswa semakin tinggi dengan metode- metode yang menarik disampaikan membuat Siswa SMPN 13 Tanggerang Selatan, mendorong siswa untuk lebih kreatif dan memiliki inovasi yang tinggi.

\section{KESIMPULAN}

Pelaksanaan Kegiatan Pengabdian Masayarakat dalam bentuk penyampaian materi serta simulasi aplikasi-aplikasi atau metode pembelajaran jarak jauh, kepada peserta didik khususnya Siswa SMPN 13 Tangerang Selatan sesuai dengan tujuan kegiatan, Pengetahuan bagaimana Sejarah Perkembangan Teknologi yang begitu cepat, dan bagaimana perkembangan Teknologi tersebut membawa pengaruh dalam Dunia Pendidikan yang melahirkan metode-metode pembelajaran dengan aplikasi-aplikasi yang mendorong kreatifitas bagi peserta didik khususnya Siswa SMPN 13 Tangerang Selatan, serta peserta didik memahami dalam Penggunaan Teknologi terkait dengan Dampak yang diberikan dari Perkembangan Teknologi khususnya didunia Pendidikan, sehingga dapat menghindari dampak negatif dari Perkembangan Teknologi dimaksud.

Dalam pelaksanaan pembelajaran guru menggunakan media berupa video, penggunaan media pembelajaran berupa video pembelajaran bertujuan untuk mempermudah peserta didik dalam memahami materi. Startegi yang digunakan guru dalam pembelajaran daring berupa pemberian waktu untuk diskusi dan tanya 


\section{Loyalitas Kreativitas Aldi Masyarakat Kreatif}

P-ISSN 2722-2101, E-ISSN 2722-4201

Program Studi Ekonomi Manajemen Universitas Pamulang

Jurnal LOKABMAS Kreatif Vol.02,No.03.Nov 2021 Hal.65-73

Email:jurnalkreatif.manajemen@gmail.com jawab kepada peserta didik sebagai suatu cara untuk melakukan pendekatan sehigga peserta didik dapat berinteraki dengan baik. selain itu metode yang digunakan guru yaitu disesuaikan dengan kharakteristik peserta didik, guru menggunakan metode ceramah karena dinilai lebih efektif untuk

\section{Menjelaskan materi pembelajaran, karena meskipun belajar secara online peserta didik tetap membutuhkan penjelasan materi oleh guru. Selain itu guru juga menggunakan metode penugasan untuk mengukur sejauh mana pemahaman peserta didik, sebelum memberikan tugas guru akan memberikan penjelasan mengenai tugas tersebut. Dalam pelaksanaan pembelajaran daring ini guru menggunakan pendekatan dengan peserta didik dengan memberikan motivasi serta selalu menanyakan keluhan peserta didik terkait pelaksanaan pembelajaran daring ini. Selanjutnya untuk penilaian dan evaluasi guru menggunakan aplikasi, untuk mengirim kembali tugas peserta didik yang telah dikoreksi. Selain itu guru juga memberikan penilaian tentang kedisiplinan peserta didik}

\section{SARAN}

Dalam mengumpulkan tugas. Kendala dalam pelaksanaan pembelajaran daring ini yaitu tidak stabilnya jaringan internet sehingga terkadang peserta didik kesulitan untuk belajar. Selain itu peserta didik juga terkadang mengalami kesulitan dalam memahami materi pembelajaran, namun guru selalu memberikan waktu lebih dengan menanyakan kepada peserta didik jika memang masih ada peserta didik yang belum mengerti tentang materitersebut maka guru akan dengan sabar memberikan penjelasan ulang.

1. Kegiatan Pengabdian Masyarakat dalam pelaksanaannya terdapat kendala yang dirasakan Siswa SMPN 13 Tangerang Selatan dalam pelaksanaan pembelajaran dengan menggunakan teknologi untuk itu disarankan: Sekolah hendaknya lebih memfasilitasi guru dalam pelaksanaan pembelajaran terutama pada pelaksanaan pembelajaran daring seperti sekarang ini.

2. Pemerintah hendaknya lebih gencar lagi memberikan dukungan terhadap peserta didik dan guru dalam melaksanakan pembelajaran daring pada masa pandemi Covid-19.

3. Guru dapat lebih mengembangkan pembelajaran yang dapat membuat kondisi belajar tetap efektif walaupun dilakukan dalam jaringan, lebih sering berkomunikasi dengan peserta didik. Guru hendaknya lebih meningkatkan kreativitasnya sebagai pendidik untuk menjadi guru yang lebih profesional.

4. Peserta didik lebih diberikan motivasi dalam belajar agar pada saat pelaksanaan belajar melalui dalam jaringan peserta didik tetap memiliki semangat yang tinggi dan dapat mengikuti proses pembelajaran dengan baik sesuai dengan tujuan pembelajaran yang akan dicapai di kelas.

\section{DAFTAR PUSTAKA}

Agus Purwanto*, R. P. (2020). Studi Eksploratif Dampak Pandemi COVID19 Terhadap Proses Pembelajaran Online di Sekolah Dasar. Volume 2 Nomor 1(2020), 2, 1-12.

Elburdah, R. P., Pasaribu, V. L. D., Rahayu, S., Septiani, F., \& Metarini, R. R. A. (2021). MOMPRENEUR PENOPANG PEREKONOMIAN KELUARGA DI MASA PANDEMI COVID-19 DENGAN BISNIS ONLINE PADA KELURAHAN PONDOK BENDA. Abdi Laksana: Jurnal Pengabdian Kepada Masyarakat, 2(1), 75-82

Luh Devi Herliandry*1, N. M. (2020, April 30). Pembelajaran Pada Masa Pandemi Covid-19. Vol. 22, No. 1, April 2020, 22, 65-70 


\section{Loyalitas Kreativitas \\ Aldi Masyarakat Kreatif}

P-ISSN 2722-2101, E-ISSN 2722-4201

Program Studi Ekonomi Manajemen Universitas Pamulang

Jurnal LOKABMAS Kreatif Vol.02,No.03.Nov 2021 Hal.65-73

Email:jurnalkreatif.manajemen@gmail.com

Endang Puji Astutik (2019,Desember 4158).pdf Analisis kota jakarta sebagai Smart City dan Penggunaan Teknologi Informasi dan Komunikasi Menuju Masyarakat Madani,jurnal artikel inovasi, jilid 6, tanggal terbit 4 Desember 2019

Jurnal Teknologi Pendidikan, JTP- vol.23 No.1(2021) 1 April 2021

Alfi Syahrinsi Alfi, L.R Retno Susanti, Sardianto Markos Siahaan 1-10.pdf Development of Multimedia Interactive Learning of Hydrosphere Material forHigh School

Jurnal Teknologi vol 6. No 2 (2021) Peran Teknologi Pendidikan pada era pandemi P.Silahi JTP- Jurnal Teknologi Pendidikan 17(1),1-14 2015, Pengembanan Model

Pasaribu, V. L. D., Agrasadya, A., Shabrina, N., \& Krisnaldy, K. (2020). Menjadi Enterpreneur Muda Yang Memiliki Jiwa Leadership Untuk Menghadapi Masa Depan. Abdi Laksana: Jurnal Pengabdian Kepada Masyarakat, 1(1).

Pasaribu, V. L. D., Susanti, F., \& Hartuti, E. T. K. (2019). Memotivasi Siswa dan Siswi SMK Letris Indonesia di Dalam Menentukan Pilihan Untuk Melanjutkan Pendidikan Atau Bekerja Setelah Lulus Sekolah. Jurnal Pengabdian Dharma Laksana, 1(2), 161-172.

Pasaribu, V. L. D., Sulaiman, S., Sutiman, S., Thaharudin, T., \& Purnomo, B. Y. (2020). Pengenalan Letak Posyandu Terdekat Dikelurahan Pisangan Dengan Manajemen Pemasaran Revolusi 4.0 Untuk Meningkatkan Pengetahuan Masyarakat Letak Dan Fungsi Posyandu Terdekat Pada Kelurahan Pisangan. Dedikasi Pkm, 1(1), 105-110.

Pasaribu, V. L. D., Oktrima, B., Prabowo, B.,
Arianto, N., \& Haryoko, U. B. (2020). Progam Pendampingan Dan Penyelenggaraan Pendidikan Anak Pada Usia Dini Terhadap Prestasi Belajar Dilingkungan Rt 020 Rw 009. Kel Giri Peni. Kec Wates. Yogyakarta. Jurnal Lokabmas Kreatif, 1(1), 71-75.

Pasaribu, V. L. D., Jannah, M., Fazar, M., Putra, S. P., Monalisa, M., \& Sofa, M. (2021). MENINGKATKAN

PRODUKTIVITAS USAHA DIMASA PANDEMI PADA IBU PKK RT 004/003 KELURAHAN SAWAH BARU CIPUTAT, TANGERANG SELATAN. Abdi Laksana: Jurnal Pengabdian Kepada Masyarakat,2(2), 295-301

Pasaribu, V. L. D., Yuniati, H. L., Pranata, R., Sembayu, R., Purba, S. M., \& Nurbayani, T. T. A. (2021). MANAJEMEN KEUANGAN UNTUK MENGHADAPI DAN BERTAHAN DI ERA COVID 19. Jurnal Abdimas Tri Dharma Manajemen, 2(2), 12-18.

Pasaribu, V. L. D., Dwiyatni, A., Sabina, C., Ridwan, M., Gunawan, D. D., \& Noviani, B. C. (2021). EVALUASI PENERAPAN 3M DIMASA PANDEMIC COVID 19. Jurnal Abdimas Tri Dharma Manajemen, 2(2), 54-60.

Pasaribu, V. L. D., Syafei, A. N., Farhan, A., Aufaizah, A., Irani, C., \& Firtiayani, S. R. (2021). PENGARUH DISPLIN PROTOKOL KESEHATAN TERHADAP PENCEGAHAN PENULARAN VIRUS COVID19. Jurnal Abdimas Tri Dharma Manajemen, 2(2), 91-98.

Pasaribu, V. L. D., Septiani, F., Rahayu, S., Lismiatun, L., Arief, M., Juanda, A., ... \& Rahim, R. (2021). Forecast Analysis of Gross Regional Domestic Product based on the Linear Regression Algorithm Technique.

Pasaribu, V. L. D., Priadi, A., Anismadiyah, V., Rahayu, S., \& Maduningtias, L. (2021). 
Loyalitas Kreativitas

Aldi Masyarakat Kreatif
P-ISSN 2722-2101, E-ISSN 2722-4201

Program Studi Ekonomi Manajemen Universitas Pamulang

Jurnal LOKABMAS Kreatif Vol.02,No.03.Nov 2021 Hal.65-73

Email:jurnalkreatif.manajemen@gmail.com
PENYULUHAN KREATIF DAN INOVATIF MENINGKATKAN MUTU PRODUKSI UMKM DI DESA BELEGA KABUPATEN GIANYAR. Pro Bono Jurnal Pengabdian Kepada Masyarakat, 1(02).

Pasaribu, V. L. D. (2021). PELATIHAN BERBASIS ONLINE DI ERA COVID-19. Jurnal Abdimas Tri Dharma Manajemen, 2(3), 26-32.

Pasaribu, V. L. D., \& Setyowati, R. (2021). ADAPTASI KEHIDUPAN NEW NORMAL PADA MASA PANDEMI COVID-19 DIYAYASAN PONDOK PESANTREN DAN PANTI ASUHAN NURUL IKHSAN KECAMATAN SETU, KOTA TANGERANG SELATAN. Jurnal Lokabmas Kreatif: Loyalitas Kreatifitas Abdi Masyarakat Kreatif, 2(2), 82-88.

Priadi, A., Pasaribu, V. L. D., Virby, S., Sairin, S., \& Wardani, W. G. (2020). Penguatan Ekonomi Kreatif Berbasis Sumber Daya Desa Dikelurahan Rempoa. Abdi Laksana: Jurnal Pengabdian Kepada Masyarakat, 1(3), 356-35

Susanti, F., Ratnawati, W., \& ivan Jazwita, D. (2020). Literasi Digital Facebook dan Whatsapp terhadap Motivasi Belajar Generasi Milenial. Jurnal Lokabmas Kreatif: Loyalitas Kreatifitas Abdi Masyarakat Kreatif, 1(2), 35-40.

Susanti, F., Lisdawati, L., Andini, R., Setiawan, R., \& Ratnawati, W. (2020). Menanamkan Jiwa dan Semangat Kewirausahaan Persaingan Menghadapi di Era Globalisasi pada Guru dan Orangtua Murid Bimbingan Belajar Bimba Pamulang Tangerang Selatan. DEDIKASI PKM, 1(1), 95100.

Susanti, F., Jaswita, D. I., \& Mardiana, S. (2020).

$\begin{array}{lr}\text { POTENSI } & \text { EKONOMI } \\ \text { KEWIRAUSAHAAN IBU RUMAH } \\ \text { TANGGA } & \text { DALAM } \\ \text { MENINGKATKAN } & \text { EKONOMI } \\ \text { MASYARAKAT } & \text { KELURAHAN } \\ \text { CEMPAKA } & \text { PUTIH } \\ \text { CIPUTAT. Jurnal Lokabmas Kreatif: } \\ \text { Loyalitas } \quad \text { Kreatifitas Abdi } \\ \text { Masyarakat Kreatif, } 1(1), 89-95 .\end{array}$

\section{FOTO DOKUMENTASI}
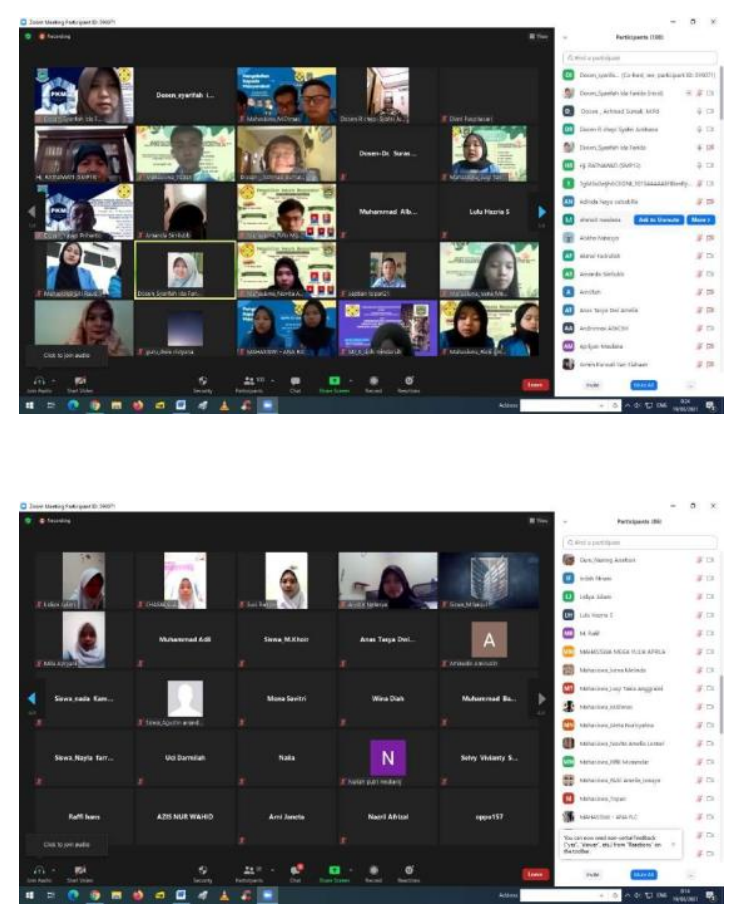
P-ISSN 2722-2101, E-ISSN 2722-4201

Loyalitas Kreativitas Program Studi Ekonomi Manajemen Universitas Pamulang

Aldi Masyarakat Kreatif

Jurnal LOKABMAS Kreatif Vol.02,No.03.Nov 2021 Hal.65-73

Email:jurnalkreatif.manajemen@gmail.com

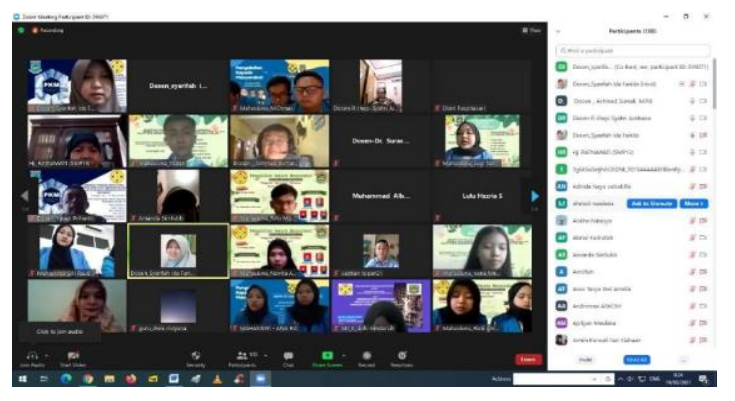


Loyalitas Kreativitas

Aldi Masyarakat Kreatif
P-ISSN 2722-2101, E-ISSN 2722-4201

Program Studi Ekonomi Manajemen Universitas Pamulang Jurnal LOKABMAS Kreatif Vol.02,No.03.Nov 2021 Hal.65-73

Email:jurnalkreatif.manajemen@gmail.com 
Loyalitas Kreativitas

Aldi Masyarakat Kreatif
P-ISSN 2722-2101, E-ISSN 2722-4201

Program Studi Ekonomi Manajemen Universitas Pamulang Jurnal LOKABMAS Kreatif Vol.02,No.03.Nov 2021 Hal.65-73

Email:jurnalkreatif.manajemen@gmail.com 
Loyalitas Kreativitas

Aldi Masyarakat Kreatif
P-ISSN 2722-2101, E-ISSN 2722-4201

Program Studi Ekonomi Manajemen Universitas Pamulang

Jurnal LOKABMAS Kreatif Vol.02,No.03.Nov 2021 Hal.65-73

Email:jurnalkreatif.manajemen@gmail.com 